\title{
Role of Scirpus mariqueter on Methane Emission from an Intertidal Saltmarsh of Yangtze Estuary
}

\author{
Yangjie Li ${ }^{1,2}$, Dongqi Wang ${ }^{2, *(1)}$, Zhenlou Chen ${ }^{2}$, Haiyan Jin ${ }^{1}$, Hong $\mathrm{Hu}^{2}$, Jianfang Chen ${ }^{1}$ and \\ Zhi Yang ${ }^{1}$ \\ 1 Key Laboratory of Marine Ecosystem and Biogeochemistry of State Ocean Administration, Second Institute \\ of Oceanography, State Ocean Administration, Hangzhou 310012, China; liyangjie@sio.org.cn (Y.L.); \\ jinhaiyan@sio.org.cn (H.J); jfchen@sio.org.cn) (J.C.); yangz@sio.org.cn (Z.Y.) \\ 2 School of Geographic Sciences, East China Normal University, Shanghai 200241, China; \\ zlchen@geo.ecnu.edu.cn (Z.C.); dhu_hong@126.com (H.H.) \\ * Correspondence: dqwang@geo.ecnu.edu.cn; Tel.: +86-21-6223-3333
}

Received: 25 December 2017; Accepted: 4 April 2018; Published: 10 April 2018

check for updates

\begin{abstract}
The role of wetland plant (Scirpus mariqueter) on methane $\left(\mathrm{CH}_{4}\right)$ emissions from a subtropical tidal saltmarsh of Yangtze estuary was investigated over a year. Monthly $\mathrm{CH}_{4}$ flux and pore-water $\mathrm{CH}_{4}$ concentration were characterized using static closed chamber technique and pore-water extraction. Measured chamber $\mathrm{CH}_{4}$ fluxes indicated that saltmarsh of the Yangtze estuary acted as a net source of atmospheric $\mathrm{CH}_{4}$ with annual average flux of $24.0 \mathrm{mgCH} \cdot \mathrm{m}^{-2}$. day ${ }^{-1}$. The maximum chamber $\mathrm{CH}_{4}$ flux was in August $\left(91.2 \mathrm{mgCH}_{4} \cdot \mathrm{m}^{-2}\right.$. day $\left.{ }^{-1}\right)$, whereas the minimum was observed in March $\left(2.30 \mathrm{mgCH} 4 \cdot \mathrm{m}^{-2} \cdot\right.$ day $\left.^{-1}\right)$. Calculated diffusion $\mathrm{CH}_{4}$ fluxes were generally less than $6 \%$ of the chamber fluxes. Significant correlations were observed between the chamber $\mathrm{CH}_{4}$ flux and rhizospheric pore-water $\mathrm{CH}_{4}$ concentration (11-15 cm: $p<0.05, R=0.732 ; 16-20 \mathrm{~cm}: p<0.05$, $R=0.777$ ). In addition, chamber $\mathrm{CH}_{4}$ fluxes from July to September constituted more than $80 \%$ of the total annual emission and were closely correlated with aboveground biomass yield of $S$. mariqueter. The results indicated that $S$. mariqueter transportation was the dominant $\mathrm{CH}_{4}$ emission pathway and it provided an efficient route for the belowground $\mathrm{CH}_{4}$ to escape into the atmosphere while avoiding oxidation, leading to $\mathrm{CH}_{4}$ emissions.
\end{abstract}

Keywords: estuarine salt marsh; vascular plant; carbon cycles; methane emission

\section{Introduction}

Methane $\left(\mathrm{CH}_{4}\right)$ is the second most important greenhouse gas in the atmosphere [1]. One of important pathways of $\mathrm{CH}_{4}$ formation is through fermentation mediated by microbiological process and controlled by oxygen availability and the amount of labile organic matter [2]. Another $\mathrm{CH}_{4}$ formation pathway is carbonate reduction, which is believed to be a main process of $\mathrm{CH}_{4}$ production in marine systems [3]. As $\mathrm{CH}_{4}$ exchange at air-soil boundary layer is determined by its net result of production and consumption, $\mathrm{CH}_{4}$ emissions at ecosystem level cannot be accurately quantified without accounting for the potential of $\mathrm{CH}_{4}$ oxidation [4-6]. It has been reported that most of the $\mathrm{CH}_{4}$ formed in the anoxic environment is biologically oxidized to $\mathrm{CO}_{2}$ before escaping out of the sediments $[7,8]$. In wetland sediments, $\mathrm{CH}_{4}$ oxidation mediated by methanotrophs could occur in both aerobic and anaerobic conditions [9-11].

There are three pathways for dissolved $\mathrm{CH}_{4}$ in sediment pore-water to reach the atmosphere: molecular diffusion, bubble ebullition, and vascular plant transport [12,13]. High belowground $\mathrm{CH}_{4}$ stock resulted from rapid microbial $\mathrm{CH}_{4}$ production creates concentration gradients at air-soil boundary layers [14], which drives $\mathrm{CH}_{4}$ diffusion following the Fick's first law [15]. In some cases, 
the diffusion fluxes were found to be smaller than bubble ebullition and vascular plants transport [16]. To adapt to long-term water flooding, wetland plants develop aerenchyma as a pathway for internal gas transport. This pathway is bidirectional such that oxygen can be transported belowground tissues and $\mathrm{CH}_{4}$ be vented to the atmosphere [17]. Wetland plants can also greatly influence $\mathrm{CH}_{4}$ production and consumption by secreting $\mathrm{O}_{2}$ and exudates in rhizosphere [18-20]. In addition, the plant transportation of $\mathrm{CH}_{4}$ could play an important role in $\mathrm{CH}_{4}$ emissions [14]. This is especially true in vegetated wetlands where plant transportation usually acts as the main emission pattern of $\mathrm{CH}_{4}[20,21]$, even though the magnitude of $\mathrm{CH}_{4}$ emissions may vary significantly among different species [20,22-24].

The Yangtze estuary, located in the subtropical area with a clear four seasons, is one of the biggest estuaries in the world. Annually, the Yangtze River transports $4.80 \times 10^{8}$ tons of sediment to the East China Sea, and about half of that settles in the estuary, thereby forming an extensive intertidal zone [25]. Thus, intertidal marshes in Yangtze estuary may play an important role in carbon cycles including both carbon sequestration and release in the regional scale. Previously, Wang et al. [26] reported the $\mathrm{CH}_{4}$ emission fluxes and seasonal influence in this area. Bu et al. [27] studied the semi-lunar tidal cycling on sediment $\mathrm{CH}_{4}$ emissions. Yin et al. [28] revealed the influences of Spartina alterniflora invasions on both $\mathrm{CH}_{4}$ and $\mathrm{N}_{2} \mathrm{O}$ fluxes from the salt marsh, just north of Yangtze estuary. However, few studies focused on the influence of the endemic plant (S. mariqueter) on $\mathrm{CH}_{4}$ emissions in Yangtze estuary. Clarification of the relative contribution of two emission pathways, molecular diffusion and plant transport, would be very useful to reveal the plants' contribution to $\mathrm{CH}_{4}$ emissions. Besides, Yangtze estuary is also faced with the invasion of the exotic Spartina alterniflora, which could greatly decrease the plant density of $S$. mariqueter, thus changing the $\mathrm{CH}_{4}$ emissions. Therefore, the objectives of this case study were: (1) to elucidate the role of S. mariqueter on methane emission; (2) to identify the seasonal $\mathrm{CH}_{4}$ emission patterns; and (3) to examine the relationship between $\mathrm{CH}_{4}$ emissions and pore-water $\mathrm{CH}_{4}$ concentrations, at representative point of an intertidal saltmarsh at Yangtze estuary.

\section{Methods and Materials}

\subsection{Study Site}

Yangtze estuarine wetlands continue extending to East China Sea rapidly because of the abundant sediment import from the upper reaches [25]. Dongtan in the east Chongming Island is the largest and most conserved intertidal wetland in Yangtze estuary, which is about $100 \mathrm{~km}^{2}$ and composed of saltmarsh and bare flat. The shape of saltmarsh is semilunar, and the widest middle part is about $4 \mathrm{~km}$ (Figure 1). Research and sampling point is selected at about the center of the saltmarsh $\left(31^{\circ} 30.111^{\prime} \mathrm{N}\right.$, $\left.121^{\circ} 59.024^{\prime} \mathrm{E}\right)$. The point is not submerged during the neap tide and submerged for several hours during the spring tide. Sampling was carried out at low tide. Phragmites, S. mariqueter and the invasive Spartina alterniflora compose the vegetation community of saltmarshes. S. mariqueter is the native species in Yangtze estuary. In general, one axillary bud per corm sprouts to form a new shoot at the depth of $20 \mathrm{~cm}$ in spring, which determines that most of the roots distribute within the depth of $20 \mathrm{~cm}$ [29]. At the base of the new shoot, constituted by a corm, usually one to three rhizomes develop and form new shoots [30]. The growing season for S. mariqueter generally occurs from late April to early November with the most active growth occurring during the three summer months (July, August and September), and it dies off at the end of the growing season and they gradually fall over. Along with the continuous sediment deposition, the dead plant will be buried by the sediment and they cannot be flow out with the tide due to the deeper root fixation [31]. 


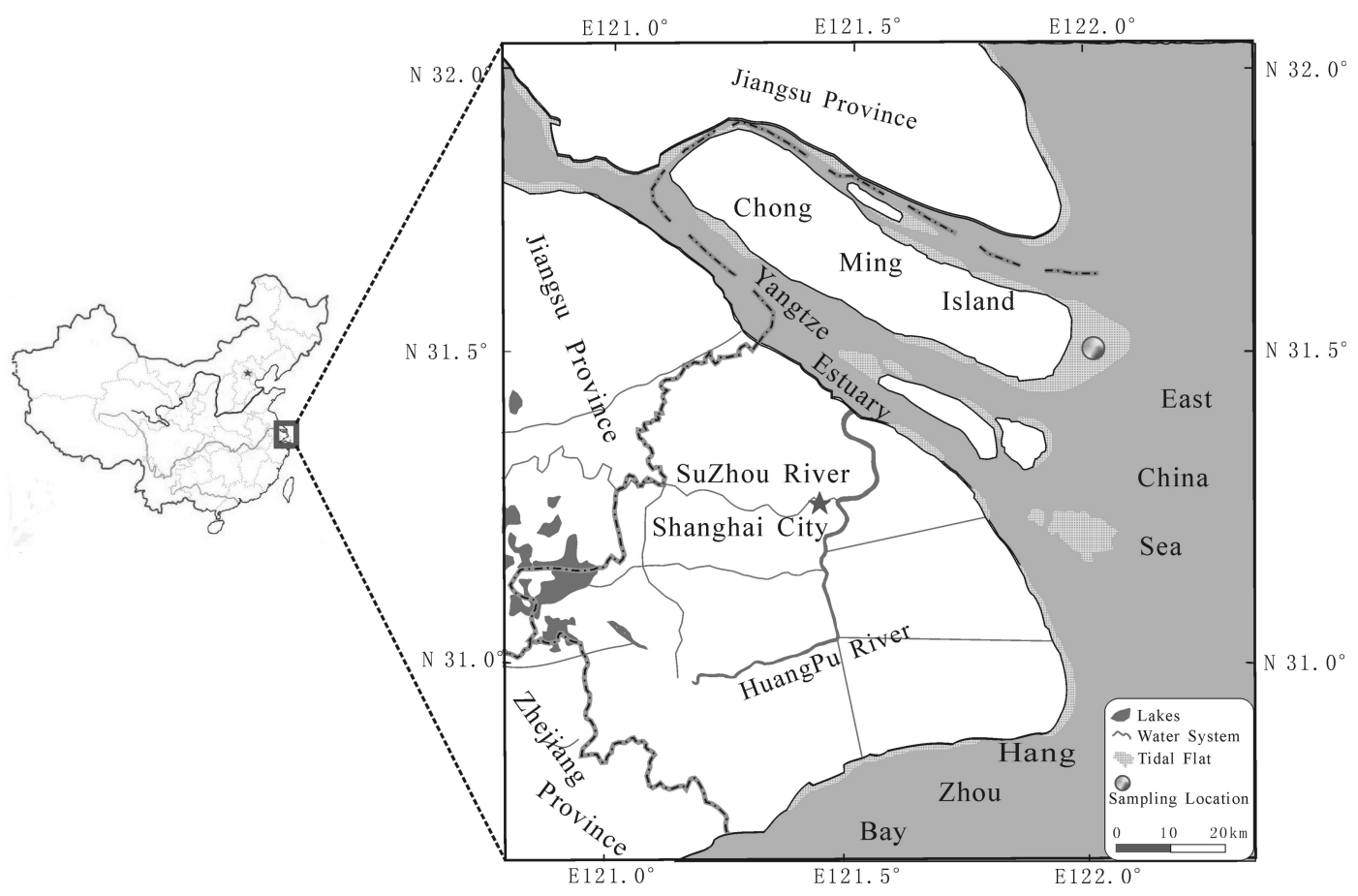

Figure 1. The sampling site in Yangtze estuary. The studied salt marsh was mainly dominated by the endemic species of S. mariqueter.

\subsection{Sampling}

A sediment core (60-cm long) was collected monthly from April to December 2011 using a PVC pipe (inner diameter: $12 \mathrm{~cm}$, length: $100 \mathrm{~cm}$ ). Core sampling was not carried out from January to March because the preparatory work was not being done during that period. The core was sealed with tapes and carried back to the laboratory for the measurement of pore-water $\mathrm{CH}_{4}$ concentration within one day.

Static closed chamber technique was adopted to measure $\mathrm{CH}_{4}$ fluxes 70 times from February to December 2011. Three stainless-steel collars were inserted into the soil to a depth of $5 \mathrm{~cm}$ including one bunch of moderate growth size of Scirpus mariqueter, half hour before gas sampling, and, then, triplicate transparent chambers made of 3-mm thickness Perspex cylinder were placed on collars, and an airtight closure was ensured by water sealing during the measurements. Considering that the vegetation height, even during the peak of the growing season, was no more than $50 \mathrm{~cm}$, the dimensions of the chambers are $50-\mathrm{cm}$ height and 30- $\mathrm{cm}$ inner diameter. Small electric fans and kerosene thermometers were fixed inside the chambers for the air blending in the chambers and the temperature measurement inside the chambers. For each chamber, a venting tube ( $5 \mathrm{~mm}$ inner diameter and $18.8 \mathrm{~m}$ long) was used to balance the air pressure between inside and outside chambers [32], and a polyethylene pipe connected with a three-way stopcock was fixed on the chamber top for sampling. All the connections and gaps were sealed by silicone gel to ensure chambers were air tight. Immediately after installing each chamber and again $30 \mathrm{~min}$ later, $180 \mathrm{~mL}$ gas sample was drawn out by using a syringe with a three-way airtight stopcock and injected into a pre-vacuumed air bag (plastic bag plated with Aluminum inside), which is inert to the greenhouse gas. Gas samples were carried back to the laboratory and analyzed for $\mathrm{CH}_{4}$.

Environmental factors including light intensity, air temperature and sediment temperature at different depths $(5 \mathrm{~cm}, 10 \mathrm{~cm}$ and $15 \mathrm{~cm})$ were recorded synchronously using a TES-1332 photometer, spirit thermometer and geothermometer at each time of gas sampling. The aboveground biomass of S. mariqueter was measured monthly from April to December. Vegetation samples were collected from seven $50 \mathrm{~cm} \times 50 \mathrm{~cm}$ randomly selected quadrats, maintaining approximately $3-5 \mathrm{~m}$ spacing between 
quadrats. In each quadrat, the aboveground vegetation was cut carefully, then the number of living shoots were counted, and the shoot weight and cross-section area were measured and recorded.

\subsection{Pore-Water $\mathrm{CH}_{4}$ Extraction}

The pore-water $\mathrm{CH}_{4}$ concentration was measured in the laboratory based on static headspace method within one day after the core was sampled. Fifty milliliters of distilled water were transported into a headspace tube equipped with a screws cap which has a hole and silicone septum. The $60-\mathrm{cm}$ long sediment cores were sliced at $1-\mathrm{cm}$ interval, and then $10 \mathrm{~mL}$ of the subsamples in each layer were put into the prepared headspace tube quickly. The tube was capped with the silicone septum immediately and set on a shaker for $20 \mathrm{~min}$ at $150 \mathrm{rpm}$ to make the sediment fully blend with the aerated distilled water forming slurry and gas equilibrium between slurry and headspace air. After 20 min of shaking, $10 \mathrm{~mL}$ gas sample was extracted with a $50 \mathrm{~mL}$ syringe from the headspace of each tube for $\mathrm{CH}_{4}$ concentration measurement.

\subsection{Sediment Properties}

The $\mathrm{CH}_{4}$ in samples was measured using an Agilent 7890A Gas Chromatography (GC) equipped with a FID detector. Sediment water content was calculated based on the mass method. The wet and dry weight of the sediment samples were separately measured before and after they were freeze-dried with a freeze dryer (CHRIST ALPHA 4-1/LD plus). Dried sediment samples were ground and sieved to analyze sediment organic carbon (SOC) based on $\mathrm{K}_{2} \mathrm{Cr}_{2} \mathrm{O}_{7}-\mathrm{H}_{2} \mathrm{SO}_{4}$ oxidation method [33]. The sediment water content (SWC) was obtained by using the difference between the wet and dry weights. Average particle size (APS) and medium diameter (MD) are measured by laser granularity meter (Coulter LS13320). Extractable nitrogen $\left(\mathrm{NO}_{3}{ }^{-}-\mathrm{N}\right.$ and $\left.\mathrm{NH}_{4}{ }^{+}-\mathrm{N}\right)$ was determined by extracting $10 \mathrm{~g}$ of dry sediment sample with $2 \mathrm{~mol} \cdot \mathrm{L}^{-1} \mathrm{KCl}$ followed by detection of $\mathrm{NO}_{3}{ }^{-} \mathrm{N}$ using a continuous flow analyzer (FUTURA, Alliance $\mathrm{Co}$.), and $\mathrm{NH}_{4}{ }^{+}-\mathrm{N}$ based on standard colorimetric method [34]. For acid volatile sulfide (AVS) measurement, approximately $2 \mathrm{~g}$ of sediment were added to the reaction flask and sparged for $2 \mathrm{~min}$ with pure $\mathrm{N}_{2}\left(120 \mathrm{~cm}^{3} \cdot \mathrm{min}^{-1}\right)$. The sulfide in the sediment was liberated by extraction with $1 \mathrm{~mol} \cdot \mathrm{L}^{-1} \mathrm{HCl}$ for $40 \mathrm{~min}$ at room temperature and then trapped in a solution of $0.2 \mathrm{~mol} \cdot \mathrm{L}^{-1}\left(\mathrm{CH}_{3} \mathrm{COO}\right)_{2} \mathrm{Zn}$ and $0.1 \mathrm{~mol} \cdot \mathrm{L}^{-1} \mathrm{CH}_{3} \mathrm{COONa}$ with a continuous $\mathrm{N}_{2}$ flow to form $\mathrm{ZnS}$. Each trap was quantified using the methylene blue method $[35,36]$.

\subsection{Data Calculating}

Chamber flux was calculated based on the following equation:

$$
F=\frac{\Delta c}{\Delta t} \cdot \frac{V}{A}
$$

FistheCH $\mathrm{H}_{4}$ fluxes at the sediment-air interface $\left(\mathrm{mgCH}_{4} \cdot \mathrm{m}^{-2} \cdot \mathrm{h}^{-1}\right), V$ is the chamber volume $\left(\mathrm{m}^{3}\right)$, $A$ is the sediment area in the base of sampling chamber $\left(\mathrm{m}^{2}\right), \frac{\Delta c}{\Delta t}$ is the change of $\mathrm{CH}_{4}$ concentration with time $\left(\mathrm{mgCH}_{4} \cdot \mathrm{L}^{-1} \cdot \mathrm{h}^{-1}\right), c=\frac{P}{R T} \times m\left(\mathrm{mgCH}_{4} \cdot \mathrm{L}^{-1}\right), P$ is the atmospheric pressure in sampling field, $R$ is the gas constant $\left(8.314 \mathrm{~J} \cdot \mathrm{mol}^{-1} \cdot \mathrm{K}^{-1}\right), T$ is the temperature (Kelvin Temperature, $\mathrm{K}$ ), and $m$ is the molar mass of the gas molecule.

Pore-water $\mathrm{CH}_{4}$ concentration was calculated by the following equation:

$$
C=\frac{\left(C_{\text {AIR }}-C_{B L A N K}\right) \times V_{A I R}+\left(C_{\text {AIR }}-C_{\text {BLANK }}\right) \times \alpha \times V_{\text {WATER }}}{V_{\text {POREWATER }}}
$$

$\mathrm{C}$ is the $\mathrm{CH}_{4}$ concentration in pore-water $\left(\mathrm{mgCH}_{4} \cdot \mathrm{L}^{-1}\right), \mathrm{C}_{\text {AIR }}$ is the measured $\mathrm{CH}_{4}$ concentration in the headspace of tubes $\left(\mathrm{mgCH}_{4} \cdot \mathrm{L}^{-1}\right), V_{A I R}$ is the volume of the headspace of tubes $(\mathrm{L})$, and $\alpha$ is the Bunsen coefficient. $V_{\text {WATER }}$ is the total volume of aerated distilled water in tubes and the pore water in 
sediment samples (L). $V_{\text {POREWATER }}$ is the volume of the pore water of the sediment sample (L). $C_{\text {BLANK }}$ is the measured $\mathrm{CH}_{4}$ concentration of the pure water $\left(\mathrm{mgCH}_{4} \cdot \mathrm{L}^{-1}\right)$.

Diffusive fluxes of $\mathrm{CH}_{4}$ were calculated from linear pore-water concentration gradients according to Fick's first law assuming steady state conditions. The diffusion equation is described as Equation (3):

$$
F_{c a l}=D_{S} \frac{\Delta C}{\Delta Z}=D_{S} \frac{C_{S}-C_{A}}{\Delta Z}
$$

where $F_{c a l}$ is the calculated diffusion $\mathrm{CH}_{4}$ flux $\left(\mu \mathrm{molCH} \mathrm{CH}_{4} \cdot \mathrm{cm}^{-2} \cdot \mathrm{s}^{-1}\right), \frac{\Delta C}{\Delta Z}$ represents the $\mathrm{CH}_{4}$ concentration change with sediment depth $\left(\mu \mathrm{molCH}_{4} \cdot \mathrm{cm}^{-3} \cdot \mathrm{cm}^{-1}\right), \Delta \mathrm{Z}$ is the diffusion distance $(\mathrm{cm})$, $C_{S}$ is measured $\mathrm{CH}_{4}$ concentration in the surface sediment pore water $\left(\mu \mathrm{molCH} \cdot \cdot \mathrm{cm}^{-3}\right), C_{A}$ is the saturation concentration of dissolved $\mathrm{CH}_{4}$ in ambient air $\left(\mu \mathrm{molCH}{ }_{4} \cdot \mathrm{cm}^{-3}\right)$, and $D s$ is the effective diffusion coefficient for $\mathrm{CH}_{4}$ in sediment pore-water. $\mathrm{Ds}$ is calculated by the polynomial regression equation obtained by the measured diffusion coefficients for $\mathrm{CH}_{4}$ in water $(D w)$ in the range $0{ }^{\circ} \mathrm{C}$ to $35{ }^{\circ} \mathrm{C}\left(\mathrm{cm}^{2} \cdot \mathrm{s}^{-1}\right)$ (83rd Edition of the Handbook of Physics and Chemistry) which yielded the relationship [37]:

$$
D w=8.889 \times 10^{-11} T^{3}-1.714 \times 10^{-9} T^{2}+3.721 \times 10^{-7} T+8.771 \times 10^{-6}
$$

and then porosity corrected by Equation (5) from Lerman [38]:

$$
D s=D w \times \phi^{2}
$$

where $\phi$ is sediment porosity. To make the calculated diffusion flux be consistent with the total emission flux, $F_{\text {cal }}$ was finally expressed in $\mathrm{mgCH}_{4} \cdot \mathrm{m}^{-2} \cdot$ day $^{-1}$.

\subsection{Statistical Analysis}

The total $\mathrm{CH}_{4}$ fluxes were presented as means of the replications. SPSS (Version 17.0) was used to perform all of the statistical data tests. Pearson correlation analyses were used to examine the relationship between fluxes and the measured environmental variables. The statistical results were regarded as significant if the $P$ values were lower than 0.05 or 0.01 .

\section{Results}

\subsection{Environmental Factors}

Table 1 shows seasonal climatic, vegetation and soil physiochemical parameters of experimental site. Air temperature exhibited significant seasonal variation with the highest and lowest temperatures in July and February, respectively. Highest biomass of S. mariqueter occurred in August $\left(692.6 \mathrm{~g} \cdot \mathrm{m}^{-2}\right)$. The number of living shoots increased with the biomass and also reached the highest value in August. Since then, the plant began to wither and almost all of them fell over on the sediment surface in December. SOC did not show substantial changes throughout the year. SWC stayed at a relatively low level from February to April but increased in the following months. APS and MD indicated that sediment was dominated by silt fractions. In terms of the extractable nitrogen, $\mathrm{NH}_{4}{ }^{+}-\mathrm{N}$ content was generally higher than that of $\mathrm{NO}_{3}{ }^{-}-\mathrm{N}$, which probably indicated that the tidal marsh was generally under denitrification condition rather than nitrification. On the other hand, the irregular variation of AVS content throughout the year suggested that the redox potential of the microenvironment may differ a lot in this estuarine system (Table 1). AVS is mainly produced by the sulfate reduction process which occurred after the $\mathrm{O}_{2}$ and $\mathrm{NO}_{3}{ }^{-}$were utilized. Thus, AVS can be seen as an index of the sediment redox condition. Monthly AVS distribution in the sediment profile is shown in Figure 2, which indicated that the AVS in the surface sediment is usually lower than the deeper sediment. Besides, the AVS showed complex variation along with depth and month. 
Table 1. Climatic, plant and soil physiochemical parameters of experimental site.

\begin{tabular}{|c|c|c|c|c|c|c|c|c|c|c|c|c|c|c|}
\hline \multirow[b]{2}{*}{ Month } & \multicolumn{5}{|c|}{ Temperature $\left({ }^{\circ} \mathrm{C}\right)$} & \multirow{2}{*}{$\begin{array}{c}\text { PAR } \\
\left(W \cdot m^{-2}\right)\end{array}$} & \multicolumn{2}{|r|}{ Biomass } & \multirow{2}{*}{$\begin{array}{c}\mathrm{SOC} \\
(\mathrm{g} \cdot \mathrm{dm} \cdot \mathrm{kg})\end{array}$} & \multirow{2}{*}{$\begin{array}{l}\text { SWC } \\
(\%)\end{array}$} & \multirow{2}{*}{$\underset{(\mu \mathrm{m})}{\mathrm{APS} / \mathrm{MD}}$} & \multirow{2}{*}{$\begin{array}{c}\mathrm{NH}_{4}{ }^{+}-\mathrm{N} \\
\left(\mathrm{mg} \cdot \mathrm{kg}^{-1}\right)\end{array}$} & \multirow{2}{*}{$\begin{array}{l}\mathrm{NO}_{3}{ }^{-}-\mathrm{N} \\
\left(\mathrm{mg} \cdot \mathrm{kg}^{-1}\right)\end{array}$} & \multirow{2}{*}{$\underset{\left(\mu \mathrm{gVS} \cdot \mathrm{g}^{-1}\right)}{\operatorname{Ag}}$} \\
\hline & AAT & ATR & GT5 & GT10 & GT15 & & $\left(\mathrm{g} \cdot \mathrm{dm} \cdot \mathrm{m}^{-2}\right)$ & $\begin{array}{l}\text { Number of Living Shoots in } \\
50 \mathrm{~cm} \times 50 \mathrm{~cm} \text { Quadrats }\end{array}$ & & & & & & \\
\hline February & 4 & $-2.0 \sim 9.0$ & 3 & 2 & 1 & $8 \sim 266$ & - & - & 7.27 & 43 & $16.81 / 23.81$ & 3.04 & 0.15 & - \\
\hline March & 12 & $7.5 \sim 14.5$ & 10 & 9 & 9 & $17 \sim 233$ & - & - & 6.91 & 39 & $15.06 / 20.23$ & 4.88 & 0.19 & 7.46 \\
\hline April & 25 & $16.0 \sim 28.0$ & 20 & 20 & 17 & $15 \sim 304$ & 44.6 & 66 & 7.59 & 36 & $14.31 / 20.07$ & 7.54 & 0.12 & 1.37 \\
\hline May & 23 & $15.5 \sim 29.5$ & 23 & 21 & 20 & $35 \sim 317$ & 105.9 & 223 & 6.78 & 55 & $12.51 / 16.86$ & 4.82 & 0.98 & 14.3 \\
\hline June & 27 & $25.0 \sim 28.5$ & 26 & 26 & 26 & $30 \sim 145$ & 433.9 & 403 & 7.86 & 54 & $7.747 / 9.527$ & 5.65 & 0.49 & 6.35 \\
\hline July & 33 & $30.0-35.5$ & 31 & 32 & 29 & $38 \sim 297$ & 364.1 & 445 & 8.42 & 66 & $7.129 / 8.744$ & 4.33 & ND & 8.28 \\
\hline August & 25 & $23.5 \sim 26.0$ & $\begin{array}{l}1 \\
25\end{array}$ & 25 & 25 & $15 \sim 98$ & $\begin{array}{l}692.1 \\
692.6\end{array}$ & 972 & $\begin{array}{l}7.42 \\
7.12\end{array}$ & 91 & $6.636 / 7.891$ & 4.98 & 0.59 & $\begin{array}{l}3.20 \\
3.43\end{array}$ \\
\hline September & 20 & $16.0 \sim 25.0$ & 25 & 24 & 23 & $38 \sim 313$ & 534.1 & 869 & 7.65 & 46 & 7.402/9.479 & 4.48 & 0.49 & 11.5 \\
\hline October & 22 & $16.0 \sim 24.0$ & 21 & 21 & 20 & $24 \sim 284$ & 263.9 & 623 & 8.01 & 55 & $8.317 / 10.81$ & 4.06 & 0.10 & 7.32 \\
\hline November & 11 & $5.5 .0 \sim 14.0$ & 14 & 14 & 14 & 19 222 & - & - & 7.78 & 69 & $8.082 / 10.28$ & 5.25 & 0.16 & 12.5 \\
\hline December & 7 & $-1.0 \sim 9.5 .0$ & 7 & 6 & 6 & $8 \sim 188$ & 130.3 & - & 7.63 & 65 & $9.096 / 11.92$ & 4.07 & 0.20 & - \\
\hline
\end{tabular}

AAT: average air temperature; ATR: Air temperature range during the sampling day; GT5: Sediment temperature at the depth of $5 \mathrm{~cm}$; GT10: Sediment temperature at the depth of $10 \mathrm{~cm}$;

GT15: Sediment temperature at the depth of $15 \mathrm{~cm}$ ) are the mean value of the daily variation. PAR (Photosynthetically Active Radiation) is shown as the variation range of the daily

continuous observations. SOC is the average soil organic carbon values of the surface $25 \mathrm{~cm}$ sediments. The rest of the sediment parameters $\left(\mathrm{SWC}, \mathrm{APS}, \mathrm{MD}, \mathrm{NH}_{4}{ }^{+}-\mathrm{N}, \mathrm{NO}_{3}{ }^{-}-\mathrm{N}\right.$ and $\left.\mathrm{AVS}\right)$

are the values of the surface $1 \mathrm{~cm}$ sediment. 


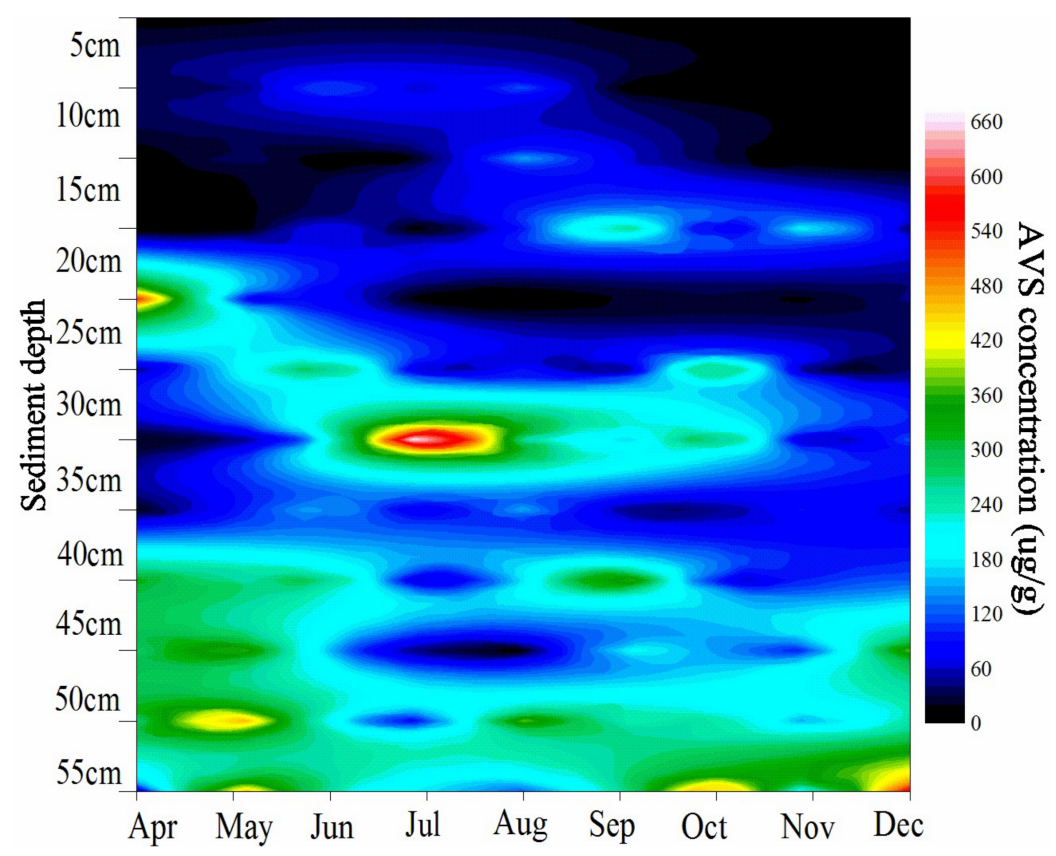

Figure 2. AVS distribution in the sediment profile.

\section{2. $\mathrm{CH}_{4}$ Fluxes}

Measured chamber $\mathrm{CH}_{4}$ fluxes showed a significant seasonal variation throughout the year with the highest $\left(91.2 \mathrm{mgCH} 4 \cdot \mathrm{m}^{-2} \cdot\right.$ day $\left.^{-1}\right)$ and lowest $\left(2.30 \mathrm{mgCH} \cdot \mathrm{m}^{-2} \cdot \mathrm{day}^{-1}\right)$ in August and March, respectively (Figure 3). The annual average chamber $\mathrm{CH}_{4}$ flux in the salt marsh was $24.0 \mathrm{mgCH} \cdot \mathrm{m}^{-2}$. day ${ }^{-1}$. The chamber $\mathrm{CH}_{4}$ flux did not increase significantly until June when the biomass of $S$. mariqueter rather than temperature increased significantly, and the chamber $\mathrm{CH}_{4}$ flux was significantly positively correlated with the aboveground biomass $(p=0.001, R=0.928)$ (Figure 4 ). Chamber $\mathrm{CH}_{4}$ flux during summer (July, August and September) constituted more than $80 \%$ of the total annual emission.

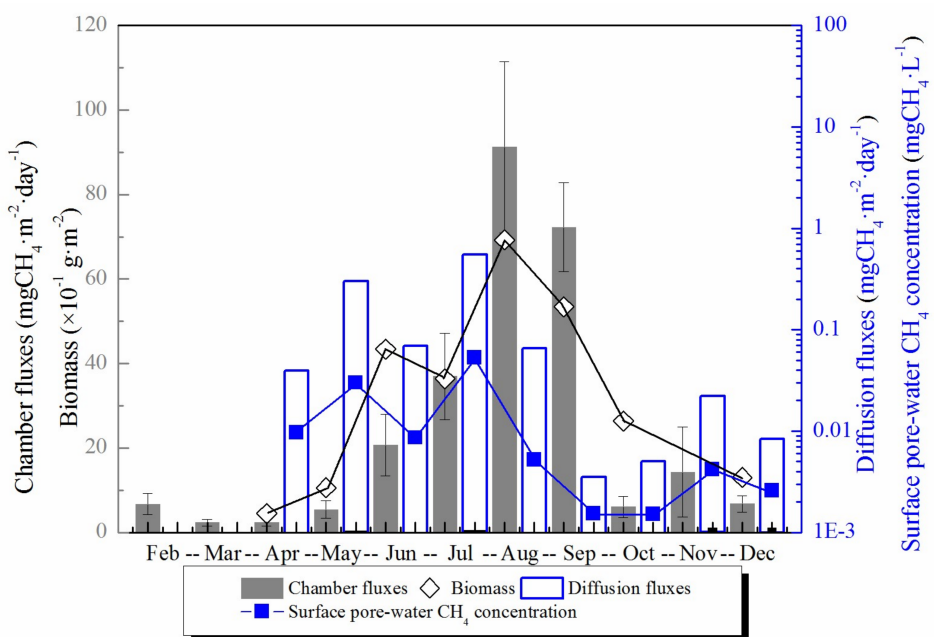

Figure 3. The total chamber $\mathrm{CH}_{4}$ fluxes, calculated diffusion $\mathrm{CH}_{4}$ fluxes, the top $1 \mathrm{~cm}$ pore-water $\mathrm{CH}_{4}$ concentration and the biomass of $S$. mariqueter in each month during the year. $\mathrm{CH}_{4}$ fluxes are presented as column graphs, while the pore-water $\mathrm{CH}_{4}$ concentration and biomass are presented as line and symbol graphs. The black graphs in the figure are integrated with the left black Y axis and the blue graphs are integrated with the right blue $\mathrm{Y}$ axis. 


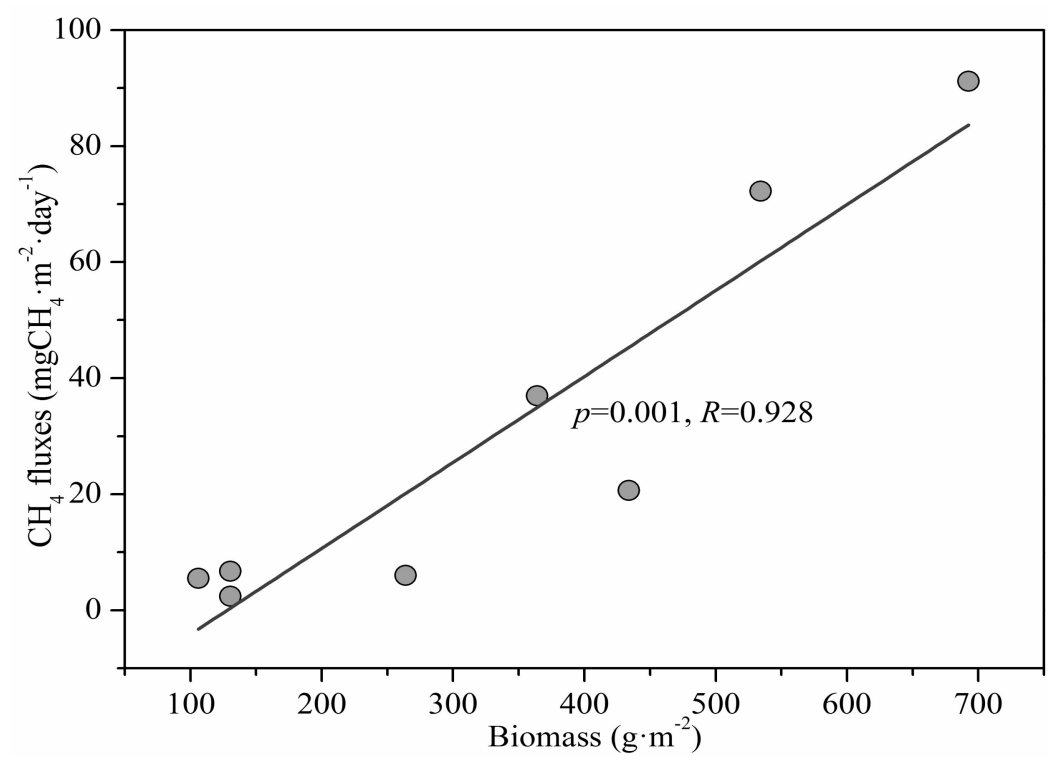

Figure 4. Correlation relationship between the $\mathrm{CH}_{4}$ fluxes and the aboveground biomass of S. mariqueter.

Calculated diffusion $\mathrm{CH}_{4}$ fluxes between the top $1 \mathrm{~cm}$ sediment and air were very low $\left(<0.55 \mathrm{mgCH}_{4} \cdot \mathrm{m}^{-2}\right.$. day $\left.{ }^{-1}\right)$ due to the low pore-water $\mathrm{CH}_{4}$ concentration in surface sediment (Figure 3$)$. There was evident seasonal variation of diffusion $\mathrm{CH}_{4}$ fluxes with the highest $\left(0.55 \mathrm{mgCH} \cdot \mathrm{m}^{-2}\right.$. day $\left.{ }^{-1}\right)$ and lowest $\left(0.0035 \mathrm{mgCH}_{4} \cdot \mathrm{m}^{-2}\right.$. day $\left.{ }^{-1}\right)$ diffusion flux in July and September, respectively (Figure 3). Overall, gas molecular diffusion method contributed a little to the total $\mathrm{CH}_{4}$ emission with the highest proportion of $5.53 \%$ in May.

In addition, regression analysis of different temperatures (air temperature and the sediment temperature at different depths $5 \mathrm{~cm}, 10 \mathrm{~cm}$ and $15 \mathrm{~cm}$ ) and chamber $\mathrm{CH}_{4}$ fluxes revealed that $\mathrm{CH}_{4}$ fluxes were best fitted with the temperature at the sediment depth of $15 \mathrm{~cm}$ where the roots of S. mariqueter were concentrated (Figure 5).
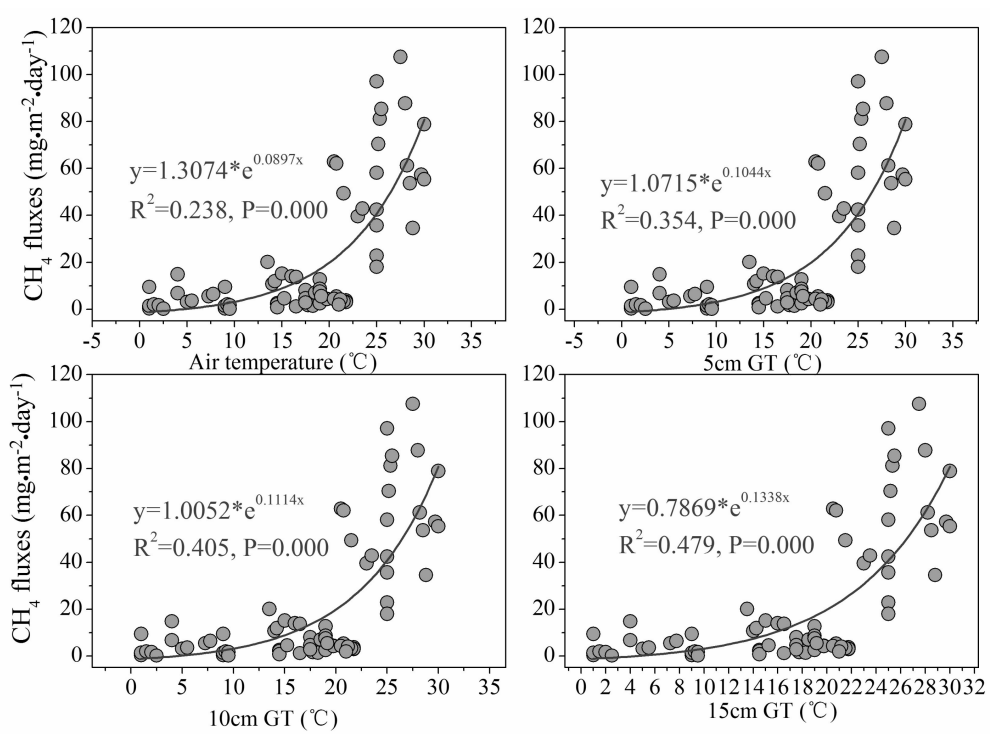

Figure 5. Relationship between chamber $\mathrm{CH}_{4}$ fluxes and temperature. Abbreviations: $5 \mathrm{~cm} \mathrm{GT,} 10 \mathrm{~cm}$ GT and $15 \mathrm{~cm}$ GT represent the sediment temperature at depths of $5 \mathrm{~cm}, 10 \mathrm{~cm}$ and $15 \mathrm{~cm}$, respectively $(n=70)$. 


\subsection{Pore-Water $\mathrm{CH}_{4}$ Concentration}

Top $1 \mathrm{~cm}$ pore-water $\mathrm{CH}_{4}$ concentration did not show any apparent seasonal variation. It was higher in the first half year and decreased to a lower value in the second half year (see Figure 3). Pore-water $\mathrm{CH}_{4}$ concentration in the top $1 \mathrm{~cm}$ was much lower than in the deeper layer sediment, resulting in a low diffusion flux. In the vertical profile, $\mathrm{CH}_{4}$ concentration increased significantly with depth. Although the pore-water $\mathrm{CH}_{4}$ concentration in deep sediment layers did not exhibit an apparent synchronously monthly variation with temperature, it did show an evident seasonal change (Figure 6). Pore-water $\mathrm{CH}_{4}$ concentration of deep sediment layer increased from May to July, decreased through October, and then reached the highest concentration $\left(8.30 \mathrm{mgCH}_{4} \cdot \mathrm{L}^{-1}\right)$ in November. After that, deep layer sediment pore-water $\mathrm{CH}_{4}$ concentration decreased again until the next April (Figure 6).
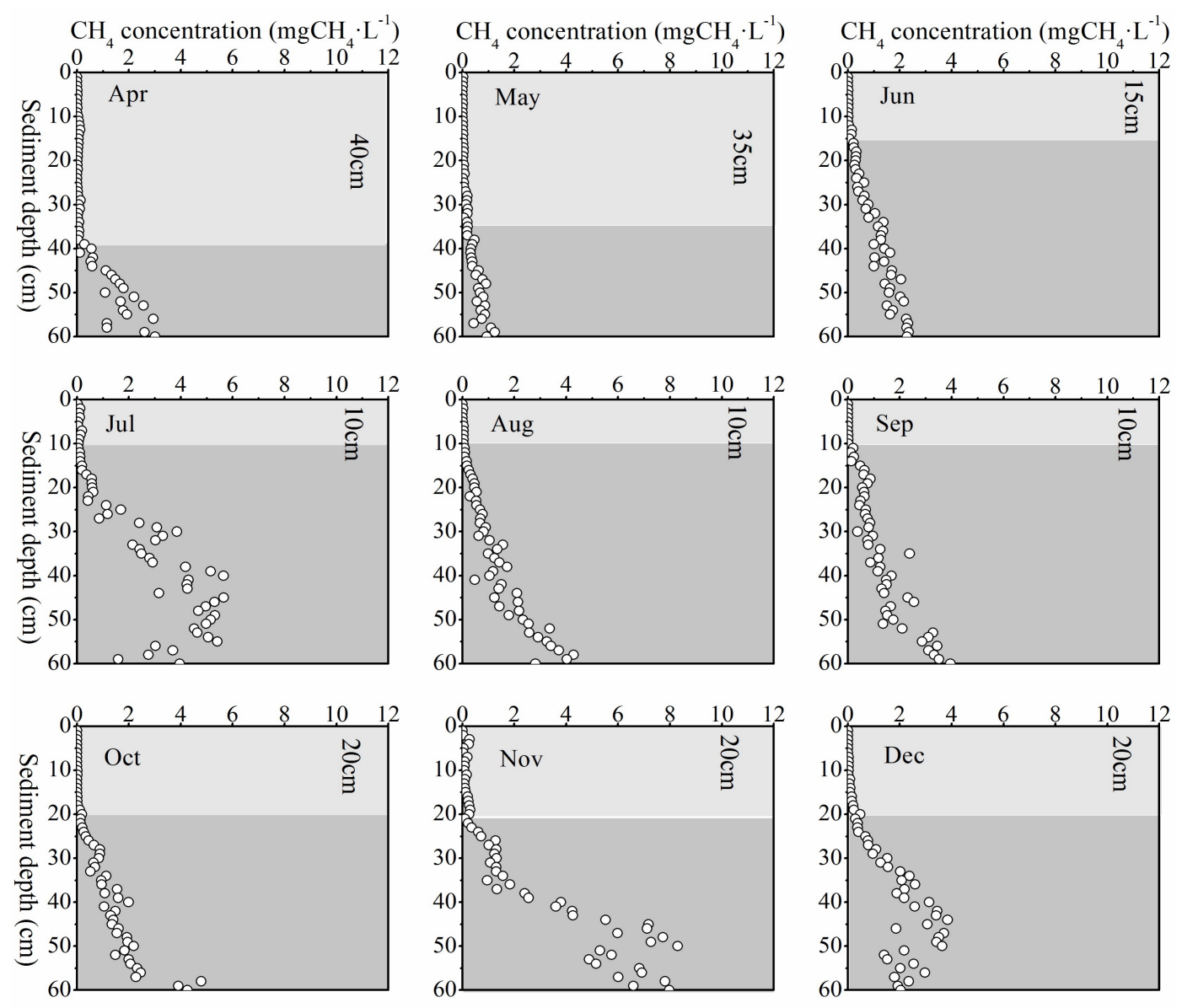

Figure 6. Monthly variation of pore-water $\mathrm{CH}_{4}$ concentration. A steep increase in pore-water $\mathrm{CH}_{4}$ concentration occurred when it exceeded $0.1 \mathrm{mgCH}_{4} \cdot \mathrm{L}^{-1}$ for each month. The light color located above the depth of this steep increase indicates the low $\mathrm{CH}_{4}$ concentrations, while the dark color indicates the high $\mathrm{CH}_{4}$ concentrations.

Along with the deep pore-water $\mathrm{CH}_{4}$ concentration variation, the depth of the steepest increase in $\mathrm{CH}_{4}$ concentration fluctuated up and down regularly during the year. The transition point of $\mathrm{CH}_{4}$ concentration increment usually occurred after the concentration exceeding $0.1 \mathrm{mgCH} \mathrm{CH}_{4} \cdot \mathrm{L}^{-1}$. The location of this interface moved up from April to July and consistently stayed at about $10 \mathrm{~cm}$ depth through September, and then it went down from October to November (Figure 6).

Relationship between the pore-water $\mathrm{CH}_{4}$ concentration and total $\mathrm{CH}_{4}$ fluxes were also analyzed through Pearson correlation analysis. Significant correlations were observed between $\mathrm{CH}_{4}$ flux and 
pore-water $\mathrm{CH}_{4}$ concentration only at the depths of $11-15 \mathrm{~cm}(p<0.05, R=0.732)$ and $16-20 \mathrm{~cm}$ $(p<0.05, R=0.777)$. (see Table 2).

Table 2. Correlation relationships between monthly methane $\left(\mathrm{CH}_{4}\right)$ fluxes and the pore-water $\mathrm{CH}_{4}$ concentration at the different depths ${ }^{a}, * p<0.05$.

\begin{tabular}{cccccc}
\hline Depth & $\mathbf{C H}_{\mathbf{4}}$ Fluxes $^{\mathbf{b}}$ & Depth & $\mathbf{C H}_{\mathbf{4}}$ Fluxes & Depth & CH $_{\mathbf{4}}$ Fluxes \\
\hline $0-5 \mathrm{~cm}$ & -0.084 & $21-25 \mathrm{~cm}$ & 0.590 & $41-45 \mathrm{~cm}$ & -0.034 \\
$6-10 \mathrm{~cm}$ & 0.146 & $26-30 \mathrm{~cm}$ & 0.192 & $46-50 \mathrm{~cm}$ & -0.065 \\
$11-15 \mathrm{~cm}$ & $0.7322^{*}$ & $31-35 \mathrm{~cm}$ & 0.279 & $51-55 \mathrm{~cm}$ & 0.219 \\
$16-20 \mathrm{~cm}$ & $0.777^{*}$ & $36-40 \mathrm{~cm}$ & 0.101 & $56-60 \mathrm{~cm}$ & 0.190 \\
\hline
\end{tabular}

a The pore-water $\mathrm{CH}_{4}$ concentration was measured at 1-cm interval, but the mean of the pore-water $\mathrm{CH}_{4}$ concentrations at 5-cm interval was used to analyze the correlation relationship between the $\mathrm{CH}_{4}$ fluxes and the underground $\mathrm{CH}_{4}$ concentrations at different depths of each month. ${ }^{\mathrm{b}}$ The correlation coefficient " $\mathrm{R}^{\text {" for }} \mathrm{CH}_{4}$ fluxes and the averaged pore-water $\mathrm{CH}_{4}$ concentrations in different depths.

\section{Discussion}

\subsection{Dominant Mechanism of $\mathrm{CH}_{4}$ Emission}

Different types of wetlands may be dominated by different $\mathrm{CH}_{4}$ emission patterns (plant mediated emission, bubble emission and the molecule diffusion) [39-41]. Anaerobic conditions in wetlands are favorable for $\mathrm{CH}_{4}$ production and accumulation, which finally create a $\mathrm{CH}_{4}$ concentration gradient between the underground and atmosphere [42]. Molecular diffusion is driven by the concentration gradient following Fick's first law of diffusion [37]. Based on Fick's first law, we calculated the molecular diffusive $\mathrm{CH}_{4}$ flux from the saltmarsh into the atmosphere. In this study, the calculated diffusion fluxes stayed at very low level with the highest diffusion flux of $0.55 \mathrm{mgCH} \mathrm{CH}_{4} \cdot \mathrm{m}^{-2} \cdot \mathrm{day}^{-1}$ in July. The proportion of diffusion fluxes accounted for $0.0048-5.53 \%$ of total monthly $\mathrm{CH}_{4}$ emission during the year. The specific reason for the weak diffusion flux is unclear due to the lack of ground water level, wind speed and the tide movement measurements. It is speculated that the wet condition in the saltmarsh is one of the most probable reasons, since it is known that water condition of the media can greatly influence the gas diffusion efficiency [43]. The S. mariqueter marsh in Yangtze estuary is located at the lower position of the tidal flat and was regularly submerged by the tide water. Surface sediments are always kept under a wet condition (this can be seen from the surface sediment water content in Table 1), which greatly inhibits the gas diffusion from surface sediment into air. In addition, the surface sediment usually stayed at a relative oxic condition, which can be seen from the low AVS concentrations in the surface sediment. Pore-water $\mathrm{CH}_{4}$ concentrations was significantly correlated with AVS concentrations $\left(p<0.01, R^{2}=0.265\right)$. It was also proven in the previous study that oxygen could easily penetrate sediment creating an oxic condition when the sediment surface exposes to the air [44]. Previous studies reported that the existence of oxidizing zones can greatly reduce the diffusion $\mathrm{CH}_{4}$ flux. According to Yun et al. [45], the aerobic methanotrophs could oxidize more than $90 \%$ of the $\mathrm{CH}_{4}$ produced in the anoxic conditions. Similar results were also obtained by Liebner et al. [46] who found that the diffusive $\mathrm{CH}_{4}$ flux from the sediment surface only accounted for less than $2 \%$ of the total flux into the atmosphere in an alpine fen due to the linearly decreased pore water $\mathrm{CH}_{4}$ concentration at the depth of $0-15 \mathrm{~cm}$. Our research also indicated that the intense oxidation of surface pore-water $\mathrm{CH}_{4}$ directly led to the weak diffusive $\mathrm{CH}_{4}$ flux.

In this study, S. mariqueter was found to facilitate $\mathrm{CH}_{4}$ emissions and the plant emitted more than $94 \%$ of the total $\mathrm{CH}_{4}$, which was consistent with many previous studies (Table 3). The highest chamber $\mathrm{CH}_{4}$ flux appeared in August when S. mariqueter was in the utmost abundant with the biggest aboveground biomass throughout the year of $692.6 \mathrm{~g} \cdot \mathrm{m}^{-2}$. The chamber $\mathrm{CH}_{4}$ fluxes of the three thriving months of S. mariqueter (July, August and September) constituted more than $80 \%$ of the total annual emission. The chamber $\mathrm{CH}_{4}$ flux decreased greatly at the end of growing season, which was consistent with the research of Chmura et al. [47]. The aerenchyma of wetland plants had two opposite 
effects on $\mathrm{CH}_{4}$ emission. Negatively, it could transport oxygen downward, creating an aerobic zone in rhizosphere [19]. The enhanced oxygen availability in sediment could inhibit $\mathrm{CH}_{4}$ production and accelerate $\mathrm{CH}_{4}$ consumption $[46,48]$. On the other hand, presence of aerenchyma in wetland plants also provides gas channels for $\mathrm{CH}_{4}$ escaping from underground to the atmosphere [16,49]. In a previous research of similar salt marsh, the net effect of these two processes was found to change along with the S. mariqueter growth stage [26]. It is indicated that the quantity of upward transported $\mathrm{CH}_{4}$ to the air through $\mathrm{S}$. mariqueter exceeded the oxidized $\mathrm{CH}_{4}$ by downward transported $\mathrm{O}_{2}$ through $\mathrm{S}$. mariqueter.

The fact that chamber $\mathrm{CH}_{4}$ fluxes were significantly correlated with aboveground biomass of S. mariqueter suggested significant effect of marsh plant growth on $\mathrm{CH}_{4}$ emission. Besides, regression analysis of different temperatures (air temperature and the sediment temperature at different depths $5 \mathrm{~cm}, 10 \mathrm{~cm}$ and $15 \mathrm{~cm}$ ) and chamber $\mathrm{CH}_{4}$ fluxes revealed that $\mathrm{CH}_{4}$ fluxes were best fitted with the temperature at the sediment depth of $15 \mathrm{~cm}$ where the roots of $S$. mariqueter were concentrated [29] (Figure 5). This indicates that the rhizospheric temperature would be a good predictor of $\mathrm{CH}_{4}$ emission. While higher temperature usually leads to stronger methanogenesis and $\mathrm{CH}_{4}$ accumulation [50], our result emphasizes the significance of the temperature increase in rhizosphere that enhanced the $\mathrm{CH}_{4}$ emission. These observations further pointed to the great contribution of plant transportation to overall $\mathrm{CH}_{4}$ emissions in this salt marsh ecosystem. Previous research showed that the wetland plant, no matter living or dead, could provide a continuous escaping route for $\mathrm{CH}_{4}$ even in winter [51]. Nonetheless, our results indicated that the strongest transportation capacity of $\mathrm{CH}_{4}$ by individual plant appeared in August with the highest $\mathrm{CH}_{4}$ flux at $2.34 \times 10^{-2} \mathrm{mgCH}_{4} \cdot \mathrm{stem}^{-1}$. day ${ }^{-1}$ in these Yangtze estuary wetlands.

Table 3. Plant contributions of different species to $\mathrm{CH}_{4}$ emissions.

\begin{tabular}{|c|c|c|c|}
\hline Vegetation Type & Proportion of Plant Emitted $\mathrm{CH}_{4}(\%)^{\text {a }}$ & Plant Treatment ${ }^{b}$ & References \\
\hline C. lasiocarpa & $73 \sim 82$ & clipping ${ }^{\mathrm{c}}$ & [21] \\
\hline C. meyeriana & $75 \sim 86$ & clipping & [21] \\
\hline Rice & 94 & clipping & [52] \\
\hline Rice & 97 & clipping & [53] \\
\hline Rice & 90 & clipping & [54] \\
\hline Reed & 60 & clipping & [52] \\
\hline Weeds & 84 & clipping & [52] \\
\hline Sedge & 79 & uprooting $d$ & [55] \\
\hline Eriophorum latifolium & 80 & uprooting & {$[20]$} \\
\hline Sedge & 94 & clipping & [56] \\
\hline Sedge & 83 & clipping & [57] \\
\hline E. vaginatum & 88 & clipping & [58] \\
\hline
\end{tabular}

a The proportion of plant transported $\mathrm{CH}_{4}$ fluxes in the total $\mathrm{CH}_{4}$ fluxes. ${ }^{\mathrm{b}}$ Different approaches to quantify the plants' effects on $\mathrm{CH}_{4}$ emissions. ${ }^{c, d}$ The most commonly adopted approaches in studying the plant transportation capacity for $\mathrm{CH}_{4} .{ }^{\mathrm{c}}$ The plant stems covered by the static closed chamber were clipped leaving the stem section on the sediment surface; ${ }^{\mathrm{d}}$ Plants covered by the static closed chamber were uprooted.

\subsection{The Implication of Pore-Water $\mathrm{CH}_{4}$ Concentration for $\mathrm{CH}_{4}$ Emission}

Static pore-water $\mathrm{CH}_{4}$ concentration from the surface to deep sediment was a net result of $\mathrm{CH}_{4}$ production and consumption, which could be affected by many environmental factors such as the redox potential, sediment organic carbon content, the distribution of methanogens and methanotroph, etc. [59-61]. In this study, the deep pore-water $\mathrm{CH}_{4}$ concentration did not exhibit synchronously seasonal variation with temperature (Figure 2), which was consistent with previous study in an alpine fen [46]. Sediment pore-water $\mathrm{CH}_{4}$ concentration profiles showed that there was an interface where the $\mathrm{CH}_{4}$ concentration steeply increased after it exceeded $0.1 \mathrm{mgCH}_{4} \cdot \mathrm{L}^{-1}$ (Figure 6). Although the $\mathrm{CH}_{4}$ concentration in the surface $10 \mathrm{~cm}$ sediment did not show apparent seasonal variations, the depth of this interface did vary and was shallower $(\sim 10 \mathrm{~cm})$ in summer than in other seasons (Figure 6). Previous studies showed that the surface sediment pore-water $\mathrm{CH}_{4}$ concentration was influenced by the oxygen concentration easily and more than $90 \%$ of the $\mathrm{CH}_{4}$ produced in anoxic conditions could 
be oxidized in the upper aerobic conditions [62]. Conversely, the pore-water $\mathrm{CH}_{4}$ concentration could be seen as the indicator of environmental oxidation-deoxidation status. In our study, we attributed the upper layer of the sediment where $\mathrm{CH}_{4}$ concentration was lower than $0.1 \mathrm{mg} \mathrm{CH}_{4} \cdot \mathrm{L}^{-1}$ to the active $\mathrm{CH}_{4}$ oxidization (aerobic and anaerobic). Above this interface, $\mathrm{CH}_{4}$ concentration was controlled by the aerobic and anaerobic oxidation process and maintained at a low level (Figure 5). Below this interface, $\mathrm{CH}_{4}$ concentration increased sharply, which was controlled by the anaerobic oxidation and production and diffusion from deeper layer. The effects of temperature on the depth of this "interface" could be explained from two aspects. On the one hand, under high temperature, oxygen penetration into sediment was generally reduced because the solubility of atmospheric oxygen decreased with temperature increase [44]. On the other hand, intensive respiration took place at high temperature, which accelerated the oxygen consumption within the surface sediment zones $[63,64]$.

The analysis of the correlation between chamber $\mathrm{CH}_{4}$ fluxes and the pore-water $\mathrm{CH}_{4}$ concentration in different depths showed that only the pore-water $\mathrm{CH}_{4}$ concentration at the depths of $11-15 \mathrm{~cm}$ and 16-20 cm, where the dense roots of $S$. mariqueter are distributed, best predicted the chamber $\mathrm{CH}_{4}$ fluxes (see Table 2). The increased temperature in summer raised the depth of reactive layer for $\mathrm{CH}_{4}$ production to the depth of plant root distribution, which directly promoted the rhizospheric $\mathrm{CH}_{4}$ uptake from sediment pore water and prevented the $\mathrm{CH}_{4}$ oxidation in diffusion. The positively correlated chamber $\mathrm{CH}_{4}$ fluxes and rhizospheric $\mathrm{CH}_{4}$ concentration revealed that overall S. mariqueter acted as a promoter of $\mathrm{CH}_{4}$ emission when taking both rhizospheric $\mathrm{CH}_{4}$ oxidation and transportation into consideration.

The lack of significant relationship between the surface $(0-10 \mathrm{~cm})$ pore-water $\mathrm{CH}_{4}$ concentration and chamber $\mathrm{CH}_{4}$ fluxes further indicated the small contribution of gas molecular diffusion to $\mathrm{CH}_{4}$ emission. Although the pore-water $\mathrm{CH}_{4}$ concentration was apparently higher in the deeper layers, it had little effect on $\mathrm{CH}_{4}$ emission, probably because most of the upward diffusive $\mathrm{CH}_{4}$ was anaerobically oxidized due to the long-distance migration [64,65]. In addition, the $\mathrm{CH}_{4}$ in the deep sediment scantly contributed little to $\mathrm{CH}_{4}$ fluxes through bubble emission because the $\mathrm{CH}_{4}$ concentration was not high enough to form gas bubbles. Previous studies have indicated that bubbles could not form until pore-water $\mathrm{CH}_{4}$ concentrations exceeded 7.1-8.0 $\mathrm{mgCH}_{4} \cdot \mathrm{L}^{-1}$ [66]. In this research, pore-water $\mathrm{CH}_{4}$ concentration in surface was only about $0.001-0.01 \mathrm{mgCH}_{4} \cdot \mathrm{L}^{-1}$, and even the highest pore-water $\mathrm{CH}_{4}$ concentration in deep sediment layer (below $45 \mathrm{~cm}$ ) was under $8.0 \mathrm{mgCH}_{4} \cdot \mathrm{L}^{-1}$.

\section{Conclusions}

This study demonstrated that S. mariqueter marsh in Yangtze estuary acted as a net source of atmospheric $\mathrm{CH}_{4}$. The annual average chamber $\mathrm{CH}_{4}$ flux was $24.0 \mathrm{mgCH} \cdot \mathrm{m}^{-2}$. day ${ }^{-1}$ with the peak flux in August when the oxidization layer became shallow (about $10 \mathrm{~cm}$ ) and the $S$. mariqueter thrived. The calculated diffusion $\mathrm{CH}_{4}$ fluxes were no more than $6 \%$ of the total fluxes, indicating that molecular diffusion was not a major pathway of $\mathrm{CH}_{4}$ emission in this salt marsh. Analysis of seasonal variation of pore-water $\mathrm{CH}_{4}$ concentration identified the dominant emission pattern as plant transport, which was evident by significantly positive correlation between $\mathrm{CH}_{4}$ concentrations in rhizosphere and chamber $\mathrm{CH}_{4}$ fluxes. In addition, generally low pore-water $\mathrm{CH}_{4}$ concentration (much less than $8.0 \mathrm{mg} \mathrm{CH}_{4} \mathrm{~L}^{-1}$ ) throughout the year prevented the formation of $\mathrm{CH}_{4}$ gas bubbles from ebullition. While wetland plant could exert an influence on rhizosphere $\mathrm{CH}_{4}$ oxidation, the transport function of the plant played a more important role in $\mathrm{CH}_{4}$ emission in the Yangtze estuary S. mariqueter marsh.

Acknowledgments: The authors are deeply indebted to Chu Wang and Huanguang Deng for their assistance with fieldwork and in the laboratory. This work was jointly supported by the National Natural Science Foundation of China (Grant No. 41473094 and No. 41671467), the Ministry of Science and Technology Project Foundation (2014FY210600), the Shanghai Municipal Natural Science Foundation (Grant No. ZR1412100), the research fund from the SKLEC (2015KYYW03), the Natural Science Project of Zhejiang Province (LQ18D060003 and LQ13D060003) and the Scientific Research Fund of the Second Institute of Oceanography, SOA (JG1515).

Author Contributions: Yangjie Li, Dongqi Wang and Zhenlou Chen designed the study; Yangjie Li, Dongqi Wang and Hong Hu performed the fieldwork and laboratory experiment; Yangjie Li wrote the manuscript; Dongqi Wang, 
Haiyan Jin and Jianfang Chen helped improve the manuscript before submission; and Dongqi Wang and Zhi Yang helped revise the manuscript according to the reviewers' comments.

Conflicts of Interest: I would like to declare on behalf of my co-authors that the work was original research that has not been published previously, and is not under consideration for publication elsewhere, in whole or in part. All of the listed authors have approved the manuscript.

\section{References}

1. IPCC. Climate Change 2013: The Physical Science Basis; Cambridge University Press: Cambridge, UK; New York, NY, USA, 2013.

2. Keller, J.K.; Sutton-Grier, A.E.; Bullock, A.L.; Megonigal, J.P. Anaerobic metabolism in tidal freshwater wetlands: I. Plant removal effects on iron reduction and methanogenesis. Estuaries Coasts 2013, 36, 457-470. [CrossRef]

3. Whiticar, M.J. Diagenetic relationships of methanogenesis, nutrients, acoustic turbidity, pockmarks and freshwater seepages in EckernfordeBay. Mar. Geol. 2002, 182, 29-53. [CrossRef]

4. Moore, T.R.; Dalva, M. Methane and carbon dioxide exchange potentials of peat soils in aerobic and anaerobic laboratory incubations. Soil Biol. Biochem. 1997, 29, 1157-1164. [CrossRef]

5. Segers, R. Methane production and methane consumption: A review of processes underlying wetland methane fluxes. Biogeochemistry 1998, 41, 23-51. [CrossRef]

6. Tang, J.; Zhuang, Q.; Shannon, R.D.; White, J.R. Quantifying wetland methane emissions with process-based models of different complexities. Biogeosciences 2010, 7, 6121-6171. [CrossRef]

7. Watson, A.; Stephen, K.D.; Nedwell, D.B.; Arah, J.R. Oxidation of methane in peat: Kinetics of $\mathrm{CH}_{4}$ and $\mathrm{O}_{2}$ removal and the role of plant roots. Soil Biol. Biochem. 1997, 29, 1257-1267. [CrossRef]

8. Fritz, C.; Pancotto, V.A.; Elzenga, J.; Visser, E.J.; Grootjans, A.P.; Pol, A.; Iturraspe, R.; Roelofs, J.G.M.; Smolders, A.J. Zero methane emission bogs: Extreme rhizosphere oxygenation by cushion plants in Patagonia. New Phytol. 2011, 190, 398-408. [CrossRef] [PubMed]

9. Smemo, K.A.; Yavitt, J.B. Anaerobic oxidation of methane: An underappreciated aspect of methane cycling in peatland ecosystems? Biogeosciences 2011, 8, 779-793. [CrossRef]

10. Liu, D.Y.; Ding, W.X.; Jia, Z.J.; Cai, Z.C. Relation between methanogenic archaea and methane production potential in selected natural wetland ecosystems across China. Biogeosciences 2011, 8, 329-338. [CrossRef]

11. Chowdhury, T.R.; Dick, R.P. Ecology of aerobic methanotrophs in controlling methane fluxes from wetlands. Appl. Soil Ecol. 2013, 65, 8-22. [CrossRef]

12. Chanton, J.P. The effect of gas transport on the isotope signature of methane in wetlands. Org. Geochem. 2005, 36, 753-768. [CrossRef]

13. Dingemans, B.J.; Bakker, E.S.; Bodelier, P.L. Aquatic herbivores facilitate the emission of methane from wetlands. Ecology 2011, 92, 1166-1173. [CrossRef] [PubMed]

14. Kao-Kniffin, J.; Freyre, D.S.; Balser, T.C. Methane dynamics across wetland plant species. Aquat. Bot. 2010, 93, 107-113. [CrossRef]

15. Lai, D.Y.F. Methane Dynamics in Northern Peatlands: A Review. Pedosphere 2009, 19, 409-421. [CrossRef]

16. Belger, L.; Forsberg, B.R.; Melack, J.M. Carbon dioxide and methane emissions from interfluvial wetlands in the upper Negro River basin, Brazil. Biogeochemistry 2011, 105, 171-183. [CrossRef]

17. Laanbroek, H.J. Methane emission from natural wetlands: Interplay between emergent macrophytes and soil microbial processes. A mini-review. Ann. Bot. 2010, 105, 141-153. [CrossRef] [PubMed]

18. Larmola, T.; Tuittila, E.S.; Tiirola, M.; Nykänen, H.; Martikainen, P.J.; Yrjälä, K.; Tuomivirta, T.; Fritze, H. The role of Sphagnum mosses in the methane cycling of a boreal mire. Ecology 2010, 91, 2356-2365. [CrossRef] [PubMed]

19. Cho, R.; Schroth, M.H.; Zeyer, J. Circadian methane oxidation in the root zone of rice plants. Biogeochemistry 2012, 111, 317-330. [CrossRef]

20. Koelbener, A.; Ström, L.; Edwards, P.J.; Venterink, H.O. Plant species from mesotrophic wetlands cause relatively high methane emissions from peat soil. Plant Soil 2010, 326, 147-158. [CrossRef]

21. Ding, W.; Cai, Z.; Tsuruta, H. Plant species effects on methane emissions from freshwater marshes. Atmos. Environ. 2005, 39, 3199-3207. [CrossRef]

22. Bubier, J.L.; Moore, T.R.; Bellisario, L.; Comer, N.T.; Crill, P.M. Ecological controls on methane emissions from a northern peatland complex in the zone of discontinuous permafrost, Manitoba, Canada. Glob. Biogeochem. Cycles 1995, 9, 455-470. [CrossRef] 
23. Koh, H.S.; Ochs, C.A.; Yu, K. Hydrologic gradient and vegetation controls on $\mathrm{CH}_{4}$ and $\mathrm{CO}_{2}$ fluxes in a spring-fed forested wetland. Hydrobiologia 2009, 630, 271-286. [CrossRef]

24. Juszczak, R.; Augustin, J. Exchange of the greenhouse gases methane and nitrous oxide between the atmosphere and a temperate peatland in central Europe. Wetlands 2013, 33, 895-907. [CrossRef]

25. Chen, X.; Zong, Y. Coastal erosion along the Changiiang deltaic shoreline, China: History and prospective. Estuar. Coast. Shelf Sci. 1998, 46, 733-742. [CrossRef]

26. Wang, D.; Chen, Z.; Xu, S. Methane emission from Yangtze estuarine wetland, China. J. Geophys. Res. 2009, 114, G02011. [CrossRef]

27. Bu, N.S.; Qu, J.F.; Zhao, H.; Yan, Q.W.; Zhao, B.; Fan, J.L.; Fang, C.M.; Li, G. Effects of semi-lunar tidal cycling on soil $\mathrm{CO}_{2}$ and $\mathrm{CH}_{4}$ emissions: A case study in the Yangtze River estuary, China. Wetl. Ecol. Manag. 2015, 23, 727-736. [CrossRef]

28. Yin, S.; An, S.; Deng, Q.; Zhang, J.; Ji, H.; Cheng, X. Spartina alterniflora invasions impact $\mathrm{CH}_{4}$ and $\mathrm{N}_{2} \mathrm{O}$ fluxes from a salt marsh in eastern China. Ecol. Eng. 2015, 81, 192-199. [CrossRef]

29. Sun, S.; Cai, Y.; An, S. Differences in morphology and biomass allocation of Scirpus mariqueter between creekside and inland communities in the Changjiang estuary, China. Wetlands 2002, 22, 786-793. [CrossRef]

30. Sun, S.; Gao, X.; Cai, Y. Variations in sexual and asexual reproduction of Scirpus mariqueter along an elevational gradient. Ecol. Res. 2001, 16, 263-274. [CrossRef]

31. Yu, Z.; Li, Y.; Deng, H.; Wang, D.; Chen, Z.; Xu, S. Effect of Scirpus mariqueter on nitrous oxide emissions from a subtropical monsoon estuarine wetland. J. Geophys. Res. 2012, 117. [CrossRef]

32. Khalil, M.A.K.; Rasmussen, R.A.; Wang, M.X.; Ren, L. Emissions of trace gases from Chinese rice fields and biogas generators: $\mathrm{CH}_{4}, \mathrm{~N}_{2} \mathrm{O}, \mathrm{CO}, \mathrm{CO}_{2}$, chlorocarbons, and hydrocarbons. Chemosphere 1990, 20, 207-226. [CrossRef]

33. Nelson, D.W.; Sommers, L.E.; Sparks, D.L.; Page, A.L.; Helmke, P.A.; Loeppert, R.H.; Soltanpour, P.N.; Tabatabai, M.A.; Sumner, M.E. Total carbon, organic carbon, and organic matter. In Methods of Soil Analysis. Part 3-Chemical Methods; Soil Science Society of America, American Society of Agronomy: Madison, WI, USA, 1996; pp. 961-1010.

34. Grasshof, K.; Ehrhard, M.; Kremling, K. Methods of Seawater Analysis, 2nd ed.; Verlag Chemie: Weiheim, Germany, 1983.

35. Lin, Y.H.; Guo, M.X.; Zhuang, Y. Determination of acid volatilesulfide and simultaneously extracted metals in sediment. Acta Sci. Circumstantiae 1997, 17, 353-358. (In Chinese)

36. Lee, B.G.; Griscom, S.B.; Lee, J.S.; Choi, H.J.; Koh, C.H.; Luoma, S.N.; Fisher, N.S. Influences of dietary uptake and reactive sulfides onmetal bioavailability from aquatic sediments. Science 2000, 287, 282-284. [CrossRef] [PubMed]

37. Hornibrook, E.R.C.; Bowes, H.L.; Culbert, A.; Gallego-Sala, A.V. Methanotrophy potential versus methane supply by pore water diffusion in peatlands. Biogeosciences 2009, 6, 1491-1504. [CrossRef]

38. Lerman, A. Geochemical Processes: Water and Sediment Environments; John Wiley: New York, NY, USA, 1979; 481p.

39. Rose, C.; Crumpton, W.G. Spatial patterns in dissolved oxygen and methane concentrations in a prairie pothole wetland in Iowa, USA. Wetlands 2006, 26, 1020-1025. [CrossRef]

40. Shoemaker, J.K.; Varner, R.K.; Schrag, D.P. Characterization of subsurface methane production and release over 3 years at a New Hampshire wetland. Geochim. Cosmochim. Acta 2012, 91, 120-139. [CrossRef]

41. Wang, Y.; Yang, H.; Ye, C.; Chen, X.; Xie, B.; Huan, C.; Zhang, J.; Xu, M. Effects of plant species on soil microbial processes and $\mathrm{CH}_{4}$ emission from constructed wetlands. Environ. Pollut. 2013, 174, $273-278$. [CrossRef] [PubMed]

42. Miao, Y.; Song, C.; Wang, X.; Sun, X.; Meng, H.; Sun, L. Greenhouse gas emissions from different wetlands during the snow-covered season in Northeast China. Atmos. Environ. 2012, 62, 328-335. [CrossRef]

43. Aubertin, M.; Aachib, M.; Authier, K. Evaluation of diffusive gas flux through covers with a GCL. Geotext. Geomembr. 2000, 18, 215-233. [CrossRef]

44. Rasmussen, H.; Jørgensen, B.B. Microelectrode studies of seasonal oxygen uptake in a coastal sediment: Role of molecular diffusion. Mar. Ecol. Prog. Ser. 1992, 81, 289-303. [CrossRef]

45. Yun, J.; Yu, Z.; Li, K.; Zhang, H. Diversity, abundance and vertical distribution of methane-oxidizing bacteria (methanotrophs) in the sediments of the Xianghai wetland, Songnen Plain, northeast China. J. Soils Sediments 2013, 13, 242-252. [CrossRef]

46. Liebner, S.; Schwarzenbach, S.P.; Zeyer, J. Methane emissions from an alpine fen in central Switzerland. Biogeochemistry 2012, 109, 287-299. [CrossRef] 
47. Chmura, G.L.; Kellman, L.; Guntenspergen, G.R. The greenhouse gas flux and potential global warming feedbacks of a northern macrotidal and microtidal salt marsh. Environ. Res. Lett. 2011, 6, 044016. [CrossRef]

48. Askaer, L.; Elberling, B.; Glud, R.N.; Kühl, M.; Lauritsen, F.R.; Joensen, H.P. Soil heterogeneity effects on $\mathrm{O}_{2}$ distribution and $\mathrm{CH}_{4}$ emissions from wetlands: In situ and mesocosm studies with planar $\mathrm{O}_{2}$ optodes and membrane inlet mass spectrometry. Soil Biol. Biochem. 2010, 42, 2254-2265. [CrossRef]

49. Song, H.; Liu, X. Anthropogenic effects on fluxes of ecosystem respiration and methane in the Yellow River Estuary, China. Wetlands 2016, 36, 113-123. [CrossRef]

50. Jerman, V.; Metje, M.; Mandić-Mulec, I.; Frenzel, P. Wetland restoration and methanogenesis: The activity of microbial populations and competition for substrates at different temperatures. Biogeosciences 2009, 6, 1127-1138. [CrossRef]

51. Brix, H. Gas exchange through dead culms of reed, Phragmites australis (Cav.) Trin. ex Steudel. Aquat. Bot. 1989, 35, 81-98. [CrossRef]

52. Holzapfel-Pschorn, A.; Conrad, R.; Seiler, W. Effects of vegetation on the emission of methane from submerged paddy soil. Plant Soil 1986, 92, 223-233. [CrossRef]

53. Schütz, H.; Holzapfel-Pschorn, A.; Conrad, R.; Rennenberg, H.; Seiler, W. A 3-year continuous record on the influence of daytime, season, and fertilizer treatment on methane emission rates from an Italian rice paddy. J. Geophys. Res. Atmos. 1989, 94, 16405-16416. [CrossRef]

54. Butterbach-Bahl, K.; Papen, H.; Rennenberg, H. Impact of gas transport through rice cultivars on methane emission from rice paddy fields. Plant Cell Environ. 1997, 20, 1175-1183. [CrossRef]

55. King, J.Y.; Reeburgh, W.S.; Regli, S.K. Methane emission and transport by arctic sedges in Alaska: Results of a vegetation removal experiment. J. Geophys. Res. Atmos. 1998, 103, 29083-29092. [CrossRef]

56. Kelker, D.; Chanton, J. The effect of clipping on methane emissions from Carex. Biogeochemistry 1997, 39, 37-44. [CrossRef]

57. Green, S.M.; Baird, A.J. A mesocosm study of the role of the sedge Eriophorum angustifolium in the efflux of methane-including that due to episodic ebullition-from peatlands. Plant Soil 2012, 351, 207-218. [CrossRef]

58. Waddington, J.M.; Roulet, N.T.; Swanson, R.V. Water table control of $\mathrm{CH}_{4}$ emission enhancement by vascular plants in boreal peatlands. J. Geophys. Res. Atmos. 1996, 101, 22775-22785. [CrossRef]

59. Stanley, E.H.; Ward, A.K. Effects of vascular plants on seasonal pore water carbon dynamics in a lotic wetland. Wetlands 2010, 30, 889-900. [CrossRef]

60. Martens, C.S.; Albert, D.B.; Alperin, M.J. Biogeochemical processes controlling methane in gassy coastal sediments-Part 1. A model coupling organic matter flux to gas production, oxidation and transport. Cont. Shelf Res. 1998, 18, 1741-1770. [CrossRef]

61. Borrel, G.; Jézéquel, D.; Biderre-Petit, C.; Morel-Desrosiers, N.; Morel, J.P.; Peyret, P.; Fonty, G.; Lehours, A.C. Production and consumption of methane in freshwater lake ecosystems. Res. Microbiol. 2011, 162, 832-847. [CrossRef] [PubMed]

62. Frenzel, P.; Thebrath, B.; Conrad, R. Oxidation of methane in the oxic surface layer of a deep lake sediment (Lake Constance). FEMS Microbiol. Lett. 1990, 73, 149-158. [CrossRef]

63. Nielsen, L.P.; Christensen, P.B.; Revsbech, N.P.; Sørensen, J. Denitrification and oxygen respiration in biofilms studied with a microsensor for nitrous oxide and oxygen. Microb. Ecol. 1990, 19, 63-72. [CrossRef] [PubMed]

64. Valentine, D.L.; Reeburgh, W.S. New perspectives on anaerobic methane oxidation. Environ. Microbiol. 2000, 2, 477-484. [CrossRef] [PubMed]

65. Caldwell, S.L.; Laidler, J.R.; Brewer, E.A.; Eberly, J.O.; Sandborgh, S.C.; Colwell, F.S. Anaerobic oxidation of methane: Mechanisms, bioenergetics, and the ecology of associated microorganisms. Environ. Sci. Technol. 2008, 42, 6791-6799. [CrossRef] [PubMed]

66. Baird, A.J.; Beckwith, C.W.; Waldron, S.; Waddington, J.M. Ebullition of methane-containing gas bubbles from near-surface Sphagnum peat. Geophys. Res. Lett. 2004, 31. [CrossRef]

(C) 2018 by the authors. Licensee MDPI, Basel, Switzerland. This article is an open access article distributed under the terms and conditions of the Creative Commons Attribution (CC BY) license (http:/ / creativecommons.org/licenses/by/4.0/). 